\title{
HUMAN REMOTE MOBILE MEDICAL INFORMATION COLLECTION METHOD BASED ON INTERNET OF THINGS AND INTELLIGENT ALGORITHM
}

\author{
MÉTODO DE COLETA DE INFORMAÇÕES MÉDICAS MÓVEIS À DISTÂNCIA BASEADO NA INTERNET DAS \\ COISASENO ALGORITMO INTELIGENTE \\ MÉTODOS DEREUNIÓN DE INFORMACIÓN SOBRE TELEMEDICINA MÓVIL BASADOS EN LA RED DE \\ MATERIA Y ALGORITMOS INTELIGENTES
}

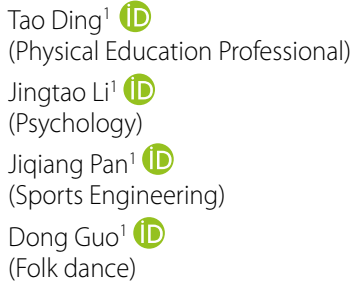

1. Shanxi University of Technology, Shaanxi hanzhong, China.

\section{Correspondence:}

haanxi hanzhong -723000 , China. qnxgpe@163.com

\begin{abstract}
In the environment of rapid social and economic development, the reform of medical informatization is constantly advancing, and the residents pay more and more attention to their own health status while improving their living standards. The traditional medical service system has some disadvantages in providing real-time, cross regional, long-term and easy-to-operate health services, which has become increasingly inadequate to meet the health needs of users. In order to solve the problem of difficulty in seeing a doctor caused by limited medical resources, and to carry out real-time health monitoring for a large number of groups suffering from chronic diseases and sub-health groups, this study conducted in-depth analysis and experimental exploration on the human remote mobile medical information collection method based on the Internet of things and intelligent algorithm. It established the information collection section by using $\mathrm{KbaC}$ clustering algorithm based on ant colony point system which, combined with a comparative study on the health indicators of related groups, has successfully proved that the Internet of things technology and intelligent algorithm for medical information collection and follow-up medical services are of certain positive significance, based on the Internet of things and other related technologies of human remote medical information collection system that can accurately and timely detect the patient's blood pressure, blood sugar and other health data, and then provide corresponding medical services.
\end{abstract}

Keywords: Internet of things; intelligent algorithm; telemedicine; information collection.

\section{RESUMO}

No ambiente de rápido desenvolvimento do nível social e econômico, a reforma da informatização médica está constantemente avançando, e os residentes prestam cada vez mais atenção ao seu próprio estado de saúde, melhorando ao Mesmo tempo seu padrão de vida. Osistema tradicional de serviços médicos tem algumas desvantagens em fornecer serviços de saúde em tempo real, transfronteiriços, de longo prazo e fáceis de operar, o que vem se tornando cada vez mais inadequado para satisfazer as necessidades de saúde dos usuários. A fim de resolver o problema a da dificuldade em consultar um médico por devido a recursos médicos limitados, e para realizar a monitorização da saúde em tempo real para um grande número de grupos que sofrem de doenças crônicas e subgrupos de saúde, este estudo conduziu uma análise aprofundada e uma exploração experimental sobre o método de coleta de informações médicas móvel à distância humana baseado na Internet das coisas e algoritmo inteligente. Estabeleceu a seção de coleta de informações utilizando o algoritmo de clustering KbaC baseado no sistema de pontos de colônias de formigas que, juntamente com um estudo comparativo sobre os indicadores de saúde dos Grupos conexos, conseguiu provar que a tecnologia da Internet das coisas e o algoritmo inteligente para a coleta de informações médicas e acompanhamento dos serviços médicos têm certa relevância positiva baseada na Internet das coisas e outras tecnologias relacionadas ao sistema de coleta de informações médicas remotas humanas, podendo detectar com precisão e tempo hábil a pressão arterial do paciente, a glicose e outros dados de saúde, e, em seguida, fornecer o serviço médico correspondente.

Descritores: Internet das coisas; algoritmo inteligente; telemedicina; coleta de informações.

\section{RESUMEN}

En un entorno de rápido desarrollo social y económico, la reforma de la informatización médica avanza constantemente y las personas prestan cada vez más atención a su estado de salud mientras mejoran su nivel de vida. El sistema de servicio médico tradicional tiene deficiencias en la prestación de servicios de salud en tiempo real, transregionales, a largo plazo y fáciles de operar, los que se han vuelto cada vez más inadecuados para satisfacer las necesidades de salud de los usuarios. Este estudio realizó un análisis con el objetivo de resolver la dificultad para consultar al médico debido a la limitación de los recursos, y de realizar un seguimiento de la salud en tiempo real de un gran número de grupos que padecen enfermedades crónicas. Dicho trabajo realizó un análisis en profundidady de exploración experimental acerca del método de recopilación de información médica humana móvil remoto basado en Internet de las cosas y el algoritmo inteligente. Estableció la sección de recopilación de información utilizando 
el algoritmo de agrupación KbaC basado en el sistema de puntos de colonia de hormigas. Esto, combinado con un estudio comparativo sobre los indicadores de salud de grupos relacionados, ha demostrado con éxito que la tecnología de Internet de las cosas y el algoritmo inteligente para la recopilación y seguimiento de información médica son de importancia positiva, y que pueden detectar de manera precisa y oportuna la presión arterial, el azúcar en sangre y otros datos de salud del paciente, para luego proporcionar la atención médica correspondiente.

Descriptores: interconexión física; algoritmos inteligentes; telemedicina; reunión de información.

\section{INTRODUCTION}

With the continuous development of modern society, people's material living standards are also constantly improving, but the aging phenomenon of China's population is becoming increasingly serious. Due to the increasing work pressure of office workers, more and more people have entered the sub-health state. ${ }^{1}$ These two types of people need to adopt mobile medical mode to monitor their physical status in real time. ${ }^{2}$ Therefore, modern medical methods must abandon the disadvantages of traditional medical methods, and optimize them by combining modern communication technology and Internet of things technology, so as to provide medical services and information for these two groups through intelligent mobile terminals, including real-time collection of patient's physical condition indicators and storage of patient's historical health data. ${ }^{3}$ In view of this, this study will focus on the Internet of things and intelligent algorithms and other related technologies, aiming to propose a feasible and stable human telemedicine information collection method.

In this study, the KbaC clustering algorithm based on ant colony algorithm and the hardware implementation method of information collection node are mainly used to construct the design method of human telemedicine information collection. The KbaC clustering algorithm based on ant colony is an efficient clustering analysis method. The biological prototype of the algorithm used in data mining clustering is ant colony nest cleaning and foraging behavior. This behavior can leave pheromone to guide the follow-up ant behavior and direction, forming a positive feedback mechanism, which has certain accuracy and quickness. The hardware implementation of information acquisition node refers to the combination of microprocessor and various sensors, real-time information collection and transmission through RF mode, with high stability and real-time.

The innovation of the research lies in the ingenious application of Internet of things technology in the construction of medical information collection theory, which combines $\mathrm{KbaC}$ clustering algorithm based on ant colony with information node collection technology organically, takes each patient's health index as an ant, integrates clustering analysis technology, and uses the characteristics of ant colony distributed search to gather the patient's medical information data set Then, each ant is transferred from one food source to another, and the ant colony state transition probability calculated by ant colony pheromone and visibility is used to classify the related health indicators of patients in each range to update the health data information. Then, each new cluster center and deviation is obtained by clustering That is to judge the actual value and time consumption of patient health index data collection; finally, output the results, that is to get the most accurate and real-time related medical information of patients, so as to provide corresponding medical services. This innovative method has successfully improved the accuracy and effectiveness of medical information collection.

Anagnostopoulos and other researchers found that with the rapid development of the Internet of things, fixed and mobile sensing devices in the Internet of things are growing significantly, and a large amount of context information is constantly generated. Through the collection and acquisition of environmental information and the simulation analysis of comprehensive and actual mobility data, an intelligent context acquisition scheme in the Internet of things environment. ${ }^{4}$ Analyzed the Internet of things technology, fault collection technology and the design principles of power equipment fault acquisition system under the Internet of things environment, and found that the application of the Internet of things technology can accurately collect relevant fault information. ${ }^{5}$ Verma P has carried out research on patient health monitoring, adopted intelligent and interactive health care measures, and incorporated mobile computing technology into the health care system based on the Internet of things. ${ }^{6}$ Shah SA and his research team studied whether the Internet of things and big data analysis can provide assistance for the construction of intelligent city environment. Through the combination of Hadoop ecosystem and spark, as well as using various data sets to verify and evaluate the system, the performance advantages of the architecture were proved?

Through the analysis of the research results of many domestic and foreign scholars in telemedicine and Internet of things related technologies, telemedicine plays an important role in the development of contemporary medicine and plays an important role in medical services. The application of Internet of things related technologies can greatly improve its performance. In view of this, this study will be based on the Internet of things and intelligent algorithm of human remote mobile medical information collection methods for in-depth exploration.

\section{Analysis and case study}

Through the research on the $\mathrm{KbaC}$ clustering algorithm based on ant colony algorithm, collection node and the construction principle of telemedicine information system, it is proved that the design and implementation of human remote mobile medical information collection system based on Internet of things and intelligent algorithm is very important for remote real-time monitoring of patient's medical information. In view of this, this study conducted a large number of analysis and case studies for the above contents. The main functions of the system include the monitoring and service of blood pressure, blood glucose, blood oxygen, etc. in the study, several patients were selected for the experiment, and the blood pressure monitoring results of patient a are shown in the figure below (Wang et al 2015).

Figure 1 shows the blood pressure monitoring results of patient a remotely obtained. By querying the patient's historical blood pressure, it is known that the latest blood pressure measurement results are systolic blood pressure $116 \mathrm{mmhg}$ and diastolic blood pressure $76 \mathrm{mmhg}$. The high pressure range of normal blood pressure is between $90 \mathrm{mmHg}$ and $140 \mathrm{mmHg}$, and the low pressure range should be $60 \mathrm{mmhg}$ to $90 \mathrm{mmHg}$. On this basis, the ideal blood pressure of human body is high pressure less than or equal to $120 \mathrm{mmh}$ and low pressure is less than or equal to $80 \mathrm{mmHg}$. Therefore, the proportion of normal blood pressure was $65.85 \%$. In addition to blood pressure, we also obtained the blood glucose data of the patient in these ten days. The broken line graph is shown below.

It can be seen from Figure 2 that the daily blood glucose changes of the patient within 10 days. Hypoglycemia occurs when the blood glucose value is lower than $3.9 \mathrm{~mol} / \mathrm{l}$, and hyperglycemia occurs when the blood glucose value is higher than $6.7 \mathrm{~mol} / \mathrm{l}$, and it is normal when the blood 
glucose is between $3.9 \mathrm{~mol} / \mathrm{l}$ and $6.7 \mathrm{~mol} / \mathrm{l}$. The medical staff can query the patient's historical blood glucose data through the background, and found that the latest blood glucose measurement value was $6.2 \mathrm{~mol} / \mathrm{l}$, and the proportion of normal blood glucose was $36.36 \%$ based on the 10 day data. The hospital health monitoring center provides users with the function of health information and physical sign data analysis. Taking the above blood pressure and blood glucose data results as an example, this paper summarizes the health data indicators of the patient in the past ten days. By comparing and analyzing the data with the normal data archives, we can find out the deficiencies in the patient's health information, and accordingly give the corresponding precautions for the patient. In addition, this study also carried out a large number of samples experiments, aiming to test the health data acquisition efficiency of the medical information collection method, the results are shown in the table $1 .{ }^{2}$

According to the data in Table 1, with the increase of the number of concurrent requests, the corresponding time in the background will gradually increase. When the amount of concurrent data is 100 , the average response time is $67 \mathrm{~ms}$, and the response time of $99 \%$ requests is $324 \mathrm{~ms}$, so patients hardly need to wait; when the amount of concurrent data is 500, the average response time is $219 \mathrm{~ms}$, and the response time of $99 \%$ requests is $3027 \mathrm{~ms}$ When the amount of concurrent data is 1000, the average response time is $260 \mathrm{~ms}$, and the response time of $99 \%$ requests is $3035 \mathrm{MS}$, which is less than 3.1 seconds, which is within the tolerance range of user waiting. The

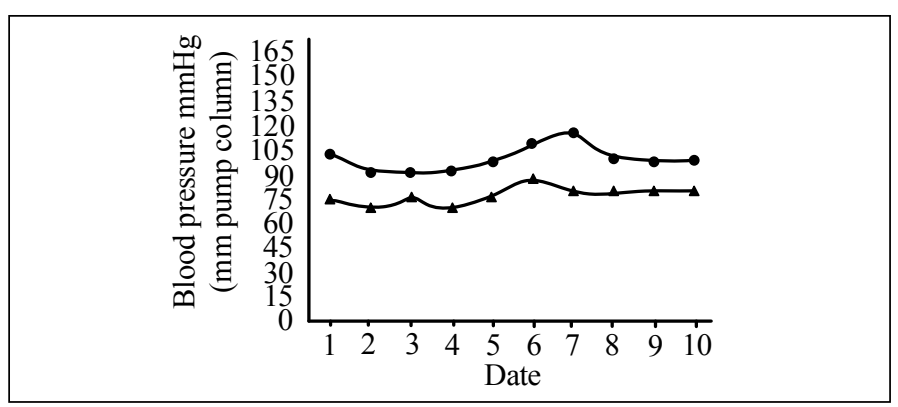

Figure 1. Blood pressure measurement results of patients.

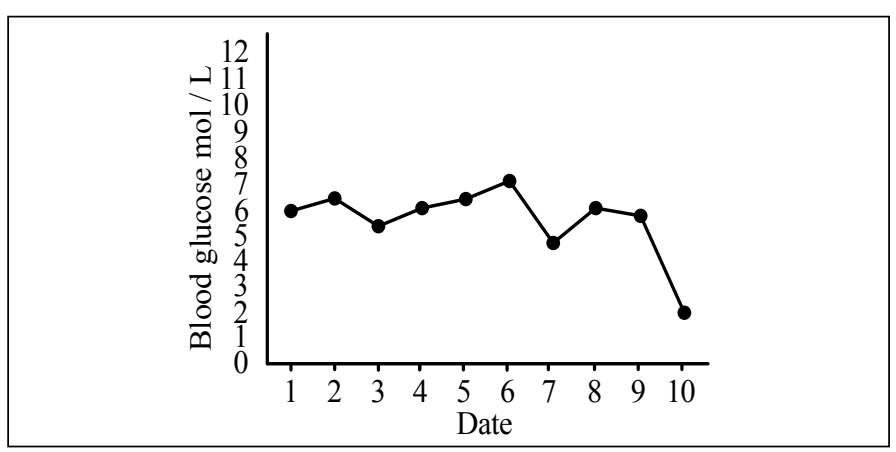

Figure 2. Blood glucose measurement results of patients.
Table 1. Concurrent data acquisition request test results.

\begin{tabular}{c|c|c|c}
\hline Name & $\begin{array}{c}\text { Test results } \\
\text { (100 samples) }\end{array}$ & $\begin{array}{c}\text { Test results } \\
\text { (500 samples) }\end{array}$ & $\begin{array}{c}\text { Test results } \\
\text { (1000 samples) }\end{array}$ \\
\hline Average response time (ms) & 67 & 219 & 260 \\
\hline 50\% request response time (ms) & 12 & 16 & 18 \\
\hline $90 \%$ request response time (ms) & 137 & 28 & 324 \\
\hline 95\% request response time (ms) & 184 & 938 & 3018 \\
\hline 99\% request response time (ms) & 324 & 3027 & 3035 \\
\hline Minimum response time (ms) & 3 & 3 & 5 \\
\hline Maximum response time (ms) & 3021 & 9034 & 9047 \\
\hline Throughput (PCS/ s) & 33.2 & 51.7 & 100.6 \\
\hline
\end{tabular}

results show that the remote mobile medical information collection method has certain rapidity and operability, and can obtain the patient's health data information instantly.. From the perspective of big data processing, the data of the patient group were compared and analyzed ((Mehrotra et al 2016). Taking the blood pressure information as an example, the normal blood pressure ratio of the patient group was summarized. The blood pressure data were mined from different angles such as age and gender, and then the blood pressure reference value of the group was obtained.

\section{CONCLUSIONS}

Internet of things (IOT) technology has been developing continuously, which provides comprehensive services for various applications by using its identification, data acquisition, data processing and fast communication capabilities. With the rapid development of the Internet of things, modern medical technology has been optimized and improved, and the application of telemedicine is more. In order to monitor and collect patients' health data in real time and accurately, compare and analyze the acquired information and historical medical information, and then provide timely medical services for patients, this study applies the Internet of things and intelligent algorithm to telemedicine information collection. Through the analysis of Internet of things related technologies, ant colony based $\mathrm{KbaC}$ clustering algorithm, information collection nodes and other content, comparative study of related patient data was carried out, which successfully proved that the above methods have a certain positive significance in telemedicine information collection. The results showed that in the health data within 10 days, the proportion of normal blood pressure and normal blood glucose of patient a was $65.85 \%$ and $36.36 \%$, respectively. Medical staff can provide targeted medical services and relevant suggestions for the data. In addition, for experiments with large sample size, the system response time is less than 3.1 seconds, within the tolerance range of user waiting, it has certain efficiency. Although some achievements have been made in this study, more experiments are needed to obtain more comprehensive results in the future research.

All authors declare no potential conflict of interest related to this article

AUTHORS' CONTRIBUTIONS: Each author has made an important personal contribution to this manuscript. Tao Ding; Jingtao Li: writing and executing manuscripts. Jiang Pan: data analysis and execution manuscripts; Dong Guo: article reviews and knowledge concepts of articles.

\section{REFERENCES}

1. Richter GM, Sun G, Lee TC, Chan RV, Flynn JT, Starren J, et al. Speed of telemedicine vs ophthalmoscopy for retinopathy of prematurity diagnosis. Am J Ophthalmol. 2009;148(1):136-42.

2. Weber J, Ebinger M, Audebert H J. Prehospital stroke care: telemedicine, thrombolysis and neuroprotection. Expert Review of Neurotherapeutics. 2015;15(7):753.

3. Hennemann-Krause L, Lopes AJ, Araújo JA, Petersen EM, Nunes RA. The assessment of telemedicine to support outpatient palliative care in advanced cancer. Palliat Support Care. 2015;13(4):1025-30.
4. Bruscato L T, Freitas E P, Heimfarth T. Self-Correcting Time Synchronization Support for Wireless Sensor Networks Targeting Applications on Internet of Things. IFAC-Papers On Line, 2016, 49(30):355-360.

5. Verma P, Sood S K. Fog Assisted-loT Enabled Patient Health Monitoring in Smart Homes. IEEE Internet of Things Journal. 2018; 5(3):1789-1796.

6. Shah SA, Seker DZ, Rathore MM, Sufian H, Sadok BY, et al. Towards Disaster Resilient Smart Cities: Can Internet of Things and Big Data Analytics be the Game Changers? . IEEE Access. 2019;7(1):91885-91903. 